\title{
PELAKSANAAN PEMBELAJARAN BERBASIS TEKNOLOGI INFORMASI DAN KOMUNIKASI DI SEKOLAH MENENGAH KEJURUAN
}

\author{
Ary Kurniawan', Fitri Nur Mahmudah ${ }^{2}$ \\ ${ }^{1}$ Program Studi Manajemen Pendidikan, Universitas Ahmad Dahlan, Yogyakarta, Indonesia \\ 2Program Studi Manajemen Pendidikan, Universitas Ahmad Dahlan, Yogyakarta, Indonesia \\ Email: ariinkreatif@gmail.com ${ }^{1}$, fitri.mahmudah@mp.uad.ac.id ${ }^{2}$
}

DOI: http://doi.org/10.33650/al-tanzim.v4i2.1156

\begin{tabular}{l|l|l} 
Received: May 2020 & Accepted: August 2020 & Published: September 2020
\end{tabular}

Abstract:

The learning process is inseperable from the application of information and communication technology in order to maintain the quality of learning. This study aims to describe the implementation of information and communication technologybased learning in the Fine Arts Expertise Program at Vocational Senior High School (Sekolah Menengah Kejuruan/SMK Negeri 5 Yogyakarta. This research use qualitative approach with case study. Data collection is taken through observation, interviews, and documentation. Data were analyzed qualitatively using the interactive analysis techniques of the Miles and Huberman models with the steps of data collection, data reduction, data display and conclution / verification. The data validity technique is triangulation technique. The results figured out that the Fine Arts Expertise Program at SMK Negeri 5 Yogyakarta had implemented Information and Communication Technology (ICT) based learning using multimedia presentations, computer equipment, laptops and LCD projectors, and learning resources from the internet.

Keywords: learning, information and communication technology, vocational education

\begin{abstract}
Abstrak:
Proses pembelajaran tidak dapat terlepas dari penerapan teknologi informasi dan komunikasi sebagai salah satu langkah untuk menjaga kualitas dan keberhasilan pelaksanaan pembelajaran. Penelitian ini bertujuan untuk mendiskripsikan pelaksanaan pembelajaran berbasis teknologi informasi dan komunikasi di Program Keahlian Seni Rupa SMK Negeri 5 Yogyakarta. Penelitian ini mengunakan pendekatan kualitatif jenis studi kasus. Pengumpulan data diambil melalui observasi, wawancara dan dokumentasi. Data dianalisis secara kualitatif dengan menggunakan teknik analisis interaktif model Miles dan Huberman dengan langkah data collection, data reduction, data display dan conclution/verification. Teknik keabsahan data dengan triangulasi teknik. Hasil penelitian menunjukkan bahwa di Program Keahlian Seni Rupa SMK Negeri 5 Yogyakarta termasuk sekolah yang sudah menerapkan pembelajaran berbasis Teknologi Informasi dan Komunikasi (TIK) dengan menggunakan media pembelajaran multimedia presentasi, menggunakan alat komputer, laptop dan LCD proyektor serta menggunakan sumber belajar dari internet. Kata Kunci: pembelajaran, teknologi informasi dan komunikasi, pendidikan kejuruan
\end{abstract}




\section{PENDAHULUAN}

Perkembangan Ilmu Pengetahuan dan Teknologi (IPTEK) pada masyarakat global yang begitu cepat mengisyaratkan perlunya perubahan dalam penyelenggaraan pendidikan. Peserta didik secara aktif perlu dikondisikan untuk mengembangkan kualitas pribadi (jujur, disiplin, mandiri, kreatif, motif berprestasi, dan etos kerja) dan kemampuan strategis (Mahmudah, 2016). Kemampuan tersebut antara lain untuk menjadikan peserta didik yang mandiri, mempunyai hubungan interpersonal, mampu bekerja sama, berfikir kreatif, mengambil keputusan, memecahkan masalah, berkolaborasi dan kemampuan manajemen diri (Amin, 2017).

Pemanfaatan teknologi informasi dan komunikasi (TIK) dalam pembelajaran di Program Keahlian Seni Rupa SMK Negeri 5 Yogyakarta telah dilakukan oleh guru dan siswa dalam pelaksanaan pembelajaran untuk meningkatkan hasil belajar siswa. Guru telah menyadari pentingnya pemanfaatan teknologi informasi dan komunikasi dalam pembelajaran di zaman sekarang ini (Khusni \& Mahmudah, 2020). Pemanfaatan TIK dilakukan dalam rangka meningkatkan efektivitas pelaksanaan proses pembelajaran yang pada akhirnya diharapkan dapat meningkatkan hasil belajar siswa serta mutu individu para peserta didik dalam hal penggunaan teknologi secara lebih tepat dan bermanfaat (Chaidar, 2014).

Guru dan siswa di Program Keahlian Seni Rupa SMK Negeri 5 Yogyakarta memanfaatan TIK dalam proses pelaksanaan pembelajaran untuk media pembelajaran, mencari sumber belajar dari internet dan sebagai alat untuk membuat tugas individu maupun kelompok. Pembiasaan secara bertahap akan terjadi efek bola salju terhadap kemampuan penguasaan TIK siswa, meningkatkan peran dan aktivitas siswa dalam proses pembelajaran yang dapat dilaksanakan tanpa dibatasi waktu dan tempat, anywhere, anytime, anything (Isjoni \& Rosnaini, 2009).

Pembelajaran tidak lagi dibatasi oleh ruang kelas. Pembelajaran sudah mampu melampaui jarak (distance learning), dan belajar dapat dilakukan di manapun (Aka, 2017). Peserta didik akan mudah memahami konsep-konsep yang abstrak (Wena, 2009); through an e-learning intervention, did improve student performance in terms of test scores... These are (a) ICT as an agent of learning, (b) site specificity, and (c) global improvement (Chandra \& Lloyd, 2008). - e-learning system design patterns are a new means for effective, efficient and transferable instructional design in technology enhanced learning environments" (Retalis et al., 2006). -Overall, the students" feedback was positive and they commented on gaining a number of skills including, using technology, group working and presentations"(Leese, 2009).

Proses pembelajaran di program keahlian seni rupa SMK Negeri 5 Yogyakarta tidak dapat terlepas dari penerapan TIK sebagai sarana dan prasarana pembelajaran di kelas. Melalui bantuan komputer dan perangkat lunak yang ada, siswa bisa memanfaatkan TIK untuk mencari sumber belajar dan mengerjakan tugas yang diberikan oleh guru. Adanya pemanfaatan TIK dalam proses pembelajaran dilaksanakan oleh siswa dengan efisien dan tepat sasaran (Syakdiyah, 2019). 
Terlebih lagi, siswa yang diposisikan sebagai subyek dalam proses belajar mengajar, akan sangat terbantu oleh computer based learning (CBL). Hal tersebut sesuai dengan yang dikemukakan (Amin, 2017) bahwa program CBL mampu mewujudkan visi dan misi, yakni meningkatkan diri atau profesionalisme dalam rangka memberi layanan terbaik bagi masyarakat serta peningkatan kualitas pendidikan dan rencana pengembangan sekolah.

TIK digunakan guru dan siswa di Program Keahlian Seni Rupa SMK Negeri 5 Yogyakarta dalam pelaksanaan pembelajaran untuk menemukan berbagai informasi dan sumber-sumber ilmu dengan mudah. ICT (including audio, video, and media based on computer feature, internet) can really help many people including teacher and student around Indonesia (Relmasira \& Thrupp, 2016).

Hal tersebut sejalan dengan yang dikemukakan Rusman (2013) bahwa pelaksanaan pembelajaran berbasis TIK, menuntut setiap siswa memanfaatkan teknologi multimedia dengan komputer untuk mengakses materi pelajaran, yang berorientasi dengan pendidik dan siswa lain dan memperoleh beberapa bentuk yang tersedia bagi siswa, sekaligus membantu mengembangkan ilmu TIK bagi siswa.

Guru dan siswa di program keahlian seni rupa SMK Negeri 5 Yogyakarta memanfaatkan TIK dalam pelaksanaan pembelajaran sebagai media presentasi untuk mempresentasikan materi pelajaran maupun tugas yang diberikan. Melalui pemanfaatan media presentasi, guru dan siswa akan lebih terbantu dalam hal waktu, hal ini dikarenakan guru tidak perlu lagi untuk menulis di papan tulis mengenai pembahasan materi yang sedang disampaikan sementara itu siswa juga dapat menggunakan lebih banyak waktu untuk berkomunikasi, berdiskusi, ataupun bertanya kepada guru (Chaidar, 2014).

SMK Negeri 5 Yogyakarta menjadi sorotan peneliti karena lembaga tersebut memiliki Program Keahlian Seni Rupa yang memiliki fasilitas perangkat TIK di tiap kelas. Hal ini berdasarkan hasil pra-penelitian yang dilakukan peneliti pada bulan Mei 2019 bersama dengan Indarto sebagai Waka Kurikulum, diperoleh informasi bahwa di setiap ruang kelas sudah terpasang berbagai komponen penunjang pembelajaran berbasis TIK, diantaranya adalah komputer, LCD proyektor, dan sound system. Hasil observasi juga menunjukkan bahwa siswa di Program Keahlian Seni Rupa SMK Negeri 5 Yogyakarta telah difasilitasi perangkat TIK berupa komputer, LCD proyektor, printer, dan pen tablet yang sudah tersedia di kelas, guna menunjang pembelajaran.

Berdasarkan latar belakang di atas, maka penelitian tentang "pelaksanaan pembelajaran berbasis TIK di Sekolah Menengah Kejuruan" perlu dilakukan, dengan tujuan untuk mengetahui bagaimana pelaksanaan pembelajaran berbasis TIK itu dijalankan. Penelitan ini difokuskan pada ruang lingkup pelaksanaan pembelajaran berbasis TIK yang dilakukan di Program Keahlian Seni Rupa SMK Negeri 5 Yogyakarta.

\section{METODE PENELITIAN}

Penelitian ini merupakan penelitian kualitatif jenis studi kasus. Alasan menggunakan pendekatan ini adalah untuk menggambarkan fenomena pada obyek penelitian secara alamiah tentang pelaksanaan pembelajaran berbasis TIK di program keahlian seni rupa SMK Negeri 5 Yogyakarta. Penelitian ini 
digambarkan secara deskriptif dalam bentuk kata-kata dan bahasa pada suatu konteks khusus yang alamiah dan dengan metode ilmiah. Data dikumpulkan dengan cara wawancara, observasi dan dokumentasi. Kepala sekolah, wakil kepala sekolah bidang kurikulum, wakil kepala sekolah bidang sarana dan prasarana, koordinator TIK, guru dan siswa adalah subyek penelitian yang ada di program keahlian seni rupa. Data dianalisis secara kualitatif dengan menggunakan teknik analisis interaktif model Miles dan Huberman dengan langkah data collection, data reduction, data display dan conclusion drawing.

Uji keabsahan data menggunakan uji kredibilitas atau kepercayaan terhadap data hasil penelitian. Pengujian kredibilitas dilakukan dengan menggunakan triangulasi teknik, yaitu pengecekan data pada sumber yang sama dengan teknik berbeda yang diperoleh melalui wawancara, observasi dan dokumentasi.

\section{HASIL DAN PEMBAHASAN}

Pelaksanaan pembelajaran berbasis teknologi informasi dan komunikasi di Program Keahlian Seni Rupa SMK Negeri 5 Yogyakarta dilakukan melalui;

\section{Awal Pembelajaran}

Guru mengawali pembelajaran dengan menyiapkan siswa untuk belajar dengan cara mengkondisikan siswa agar tenang, salam dan berdo'a bersama, menanyakan kabar siswa, presensi siswa kemudian memberikan apersepsi dan dilanjutkan dengan memulai pembelajaran. Guru melakukan apersepsi di awal pembelajaran dengan mengingatkan kembali tentang materi yang telah dipelajari pada pertemuan sebelumnya melalui pertanyaan-pertanyaan yang diajukan kepada siswa.

Guru juga menjelaskan tujuan pembelajaran dan kompetensi dasar yang akan dicapai siswa dalam pembelajaran setiap mengawali pembelajaran. Namun ada juga guru yang tidak menjelaskan tujuan pembelajaran dan kompetensi dasar yang akan dicapai siswa di awal pelajaran, dikarenakan sudah disampaikan di awal mulai materi atau kompetensi dasar. Aktivitas pembelajaran dilakukan guru secara langsung dengan menyampaikan terlebih dahulu kegiatan atau materi yang akan dilakukan pada pelaksanaan pembelajaran pada hari tersebut.

\section{Inti Pembelajaran}

\section{Eksplorasi}

Guru selalu melibatkan siswa dalam mencari sumber informasi mengenai materi yang akan dipelajari dengan memanfaatkan TIK melalui internet dengan browsing, searching, dan melihat tayangan dari youtube menggunakan komputer yang telah disediakan sekolah maupun dengan smartphone android yang dimiliki siswa sendiri.

Pendekatan maupun metode pembelajaran yang digunakan oleh guru sangat beragam pada setiap pembelajaran. Metode yang digunakan dalam pembelajaran diantaranya diskusi, ceramah, praktek langsung, kerja proyek, student center learning, discovery learning, peer teaching, klasikal, tanya jawab dan konsultasi. Guru tidak mengalami kesulitan dalam menerapkan metode 
pembelajaran tersebut. Pendekatan dan metode pembelajaran yang beragam pada pembelajaran digunakan guru untuk mengatasi kesulitan dalam menghadapi siswa diproses pembelajaran.

Penggunaan media pembelajaran, alat dan sumber belajar yang berbasis teknologi informasi dan komunikasi dalam pembelajaran ditujukan tuntuk membimbing siswa yang mengalami kesulitan dengan memberikan jawaban yang sesuai dengan yang ditanyakan siswa. Media pembelajaran yang digunakan guru dalam pembelajaran yaitu bahan tayang atau materi powerpoint (PPT), aplikasi atau Corel, Photoshop, Blender. Alat belajar yang digunakan laptop, LCD proyektor dan komputer. Sumber belajar yang digunakan guru yaitu buku elektronik, video referensi, Youtube, dan internet. Guru menggunakan media pembelajaran, alat dan sumber belajar tersebut berdasarkan kebutuhan masa kini, materi yang didapat bisa beragam dan berdasarkan kurikulum yang ada. Selain guru, siswa juga menggunakan media pembelajaran dan sumber belajar berbasis teknologi informasi dan komunikasi.

Selain aktivitas pembelajaran di kelas, siswa juga melaksanakan pembelajaran di laboratorium komputer khususnya di bengkel atau studio komputer dan di lapangan. Melihat pameran merupakan kegiatan yang dilakukan siswa saat berada di lapangan untuk menambah wawasan dan pengalaman siswa. Mengerjakan tugas dan bereksperimen merupakan aktivitas yang dilakukan siswa saat di laboratorium atau bengkel komputer. Peran guru dalam aktivitas tersebut adalah mendampingi, mengawasi, membimbing, memberikan informasi dan memotivasi siswa.

\section{Elaborasi}

Aktivitas siswa dalam pembelajaran di antaranya mengamati, menganalisa, mengerjakan tugas, praktek, diskusi, dan presentasi. Guru selalu membiasakan siswa membaca dengan memanfaatkan teknologi informasi dan komunikasi menggunakan komputer yang ada di sekolah maupun smartphone yang dimiliki siswa.

Guru juga memberikan tugas kepada siswa, baik itu tugas di sekolah maupun tugas yang dikerjakan di rumah. Penugasan guru ada dua macam, yaitu tugas individu dan tugas kelompok, namun guru lebih sering memberikan tugas individu karena membuat karya itu harus dari ide kreatif siswa sendiri. Sementara itu, tugas kelompok yang sering diberikan adalah diskusi dan praktek membuat karya sesuai dengan tugas yang diberikan. Guru mendorong siswa agar dapat berlatih memunculkan gagasan. Cara yang dilakukan guru dalam hal ini adalah dengan memberi motivasi, menampilkan karya-karya dari kakak kelas, menayangkan gambar internet dan memberikan contoh karya yang sudah jadi.

Guru selalu membimbing siswa agar dapat berfikir, menganalisis, menyelesaikan masalah dan bertindak tanpa rasa takut, guru selalu membimbing dengan memberi motivasi, memberikan kesempatan siswa untuk mencoba, memberikan pertanyaan, berdiskusi, mengevaluasi, dan mempresentasikan karya. 
Sebagai fasilitator dalam pembelajaran, guru memfasilitasi siswa agar dapat belajar secara kooperatif dan kolaboratif dengan memberikan fasilitas alat, mencari informasi di internet dan memberikan tugas dengan berdiskusi. Guru juga memfasilitasi siswa agar dapat berkompetisi secara sehat untuk meningkatkan prestasi belajar dengan memberikan waktu konsultasi kapan saja melalui media sosial whatsapp, memberikan semangat, memberi motivasi, mengevaluasi dan memfasilitasi alat.

Guru memfasilitasi siswa dalam membuat laporan eksplorasi dengan memberikan bimbingan, memberi fasilitas media pendukung seperti komputer untuk mengetik laporan dan printer untuk mencetak hasil laporan. Ketika menyajikan hasil kerja, guru memfasilitasi siswa dengan memberikan bimbingan, menyediakan alat dan bahan, serta menyiapkan media pendukung. Selain itu, guru juga mendorong siswa untuk menyajikan hasil kerja dengan memanfaatkan teknologi informasi dan komunikasi dengan memotivasi, memberikan bimbingan dan menyediakan alat untuk presentasi. Teknologi informasi dan komunikasi dalam hal ini dimanfaatkan oleh siswa sebagai sumber informasi, media dan alat pembelajaran serta untuk menyajikan hasil kerja.

\section{Konfirmasi}

Guru selalu memberikan umpan balik positif dan penguatan kepada siswa dengan memuji hasil karya siswa yang di upload di instagram, dievaluasi, diberi contoh dan memotivasi serta memberikan hadiah. Guru memberikan konfirmasi terhadap hasil eksplorasi dan elaborasi siswa dengan memberikan tanggapan terhadap karya yang dihasilkan, memberi catatan, memberi saran dan membimbing siswa selama proses pembelajaran. Selain itu, guru juga memfasilitasi siswa untuk melakukan refleksi dengan berkomunikasi antara guru dan siswa, memberikan kesempatan kepada siswa untuk saling menilai, mendekat kepada siswa satu per satu dan menanyakan siswa melalui teman dan guru yang lain.

\section{Akhir Pembelajaran}

Guru membuat kesimpulan di akhir pembelajaran dengan mengingatkan untuk mengumpulkan karya, mencatat siapa saja yang belum mengumpulkan karya dan mencatat materi yang belum jelas. Setelah itu, guru melakukan penilaian pembelajaran. Penilaian dilakukan setiap materi kompetensi dasar telah selesai dengan memberikan saran dan evaluasi terhadap karya yang dikumpulkan. Guru juga melakukan refleksi pembelajaran dengan memberikan pertanyaan, menampilkan karya dan memberikan masukan terhadap hasil karya.

Umpan balik diberikan untuk mengetahui hasil proses dan hasil belajar siswa melalui pujian, memberikan evaluasi dan memberikan apresiasi serta melakukan tanya jawab. Selain itu, guru juga memberikan tindak lanjut pembelajaran dengan memberikan waktu untuk remidi, perbaikan, penambahan tugas, pengulangan materi, konsultasi dan evaluasi karya. Terakhir, guru selalu menyampaikan rencana pembelajaran yang akan dilaksanakan pada pertemuan selanjutnya. 
Secara teoritis, pelaksanaan pembelajaran tersebut di atas, merupakan implementasi dari rencana pelaksanaan pembelajaran yang meliputi kegiatan pendahuluan, kegiatan inti dan kegiatan penutup. Guru memiliki kewajiban kepada para siswa untuk memberikan ilmu sesuai dengan anjuran Rasulullah SAW:

Artinya: "Menuntut ilmu itu wajib atas setiap muslim"

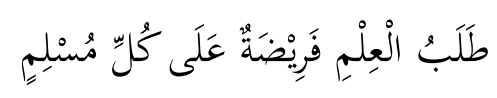

Hadits tersebut menginsyaratkan tentang pentingnya proses pembelajaran yang dilakukan oleh guru dan siswa di dalam kelas. Guru mengawali pembelajaran dengan menyiapkan siswa untuk belajar dengan cara mengkondisikan siswa agar tenang, salam dan berdo'a bersama, menanyakan kabar siswa, presensi siswa kemudian memberikan apersepsi kemudian memulai pembelajaran. Guru melakukan apersepsi di awal pembelajaran dengan mengingatkan kembali tentang materi yang telah dipelajari pada pertemuan sebelumnya melalui pertanyaan-pertanyaan yang diajukan kepada siswa. Proses yang di awali dengan berdoa ini sesuai dengan firman Allah dalam Q.S. Al-Mu'min : 60 :

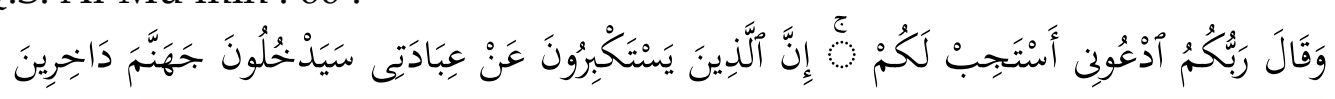

Artinya: Dan Tuhanmu berfirman: "Berdoalah kepada-Ku, niscaya akan Kuperkenankan bagimu. Sesungguhnya orang-orang yang menyombongkan diri dari menyembah- $\mathrm{Ku}$ akan masuk neraka Jahannam dalam keadaan hina dina".

Kegiatan pendahuluan pada awal pembelajaran yaitu; guru menyiapkan peserta didik secara psikis dan fisik untuk mengikuti proses pembelajaran dengan mengucapkan salam, menyapa, berdo'a dan dilanjutkan presensi. Di samping itu, guru juga mengatur siswa untuk masuk ke kelas, mengajak siswa agar tenang dan menanyakan kabar serta membangkitkan motivasi dan memfokuskan perhatian siswa untuk berpartisipasi aktif dalam proses pembelajaran (Husnurofik et al., 2019).

Psikis dan fisik siswa yang baik akan menjadikan siswa memiliki kesiapan penuh untuk mengikuti proses pembelajaran. Guru juga mengajukan pertanyaan-pertanyaan yang mengaitkan pengetahuan sebelumnya dengan materi yang dipelajari di awal pembelajaran. Hal ini dilakukan untuk memperbaiki struktur pengetahuan yang telah dimiliki siswa, memotivasi siswa untuk lebih aktif di kelas dan untuk meningkatkan kemampuan berfikir siswa.

Guru juga menjelaskan tujuan pembelajaran atau kompetensi dasar yang akan dicapai siswa di awal pembelajaran. Hal ini dilakukan untuk membangkitkan motivasi belajar siswa agar siswa memiliki tingkat kesiapan belajar yang tinggi, sehingga apa yang diajarkan oleh guru akan mudah dimengerti dan dipahami dengan baik. 
Motivasi belajar yang diberikan oleh guru pada para siswa ini terkandung secara implisit dalam Q.S. Al-Anam : 50 :

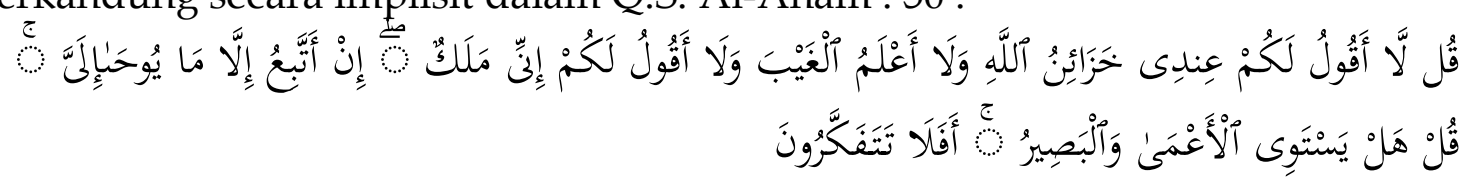

Artinya: "Katakanlah: Aku tidak mengatakan kepadamu, bahwa perbendaharaan Allah ada padaku, dan tidak (pula) aku mengetahui yang ghaib dan tidak (pula) aku mengatakan kepadamu bahwa aku seorang malaikat. Aku tidak mengikuti kecuali apa yang diwahyukan kepadaku. Katakanlah: "Apakah sama orang yang buta dengan yang melihat?" Maka apakah kamu tidak memikirkan(nya)?".

Ayat tersebut menjelaskan tentang pentingnya motivasi belajar bagi siswa, sehingga guru harus mampu menstimulasi motivasi belajar tersebut menjadi lebih baik. Guru juga menyampaikan cakupan materi dan penjelasan uraian kegiatan sesuai silabus dan rencana pelaksanaan pembelajaran agar siswa lebih memahami dan mengerti lebih awal mengenai gambaran materi yang akan dipelajari. Guru juga menjelaskan tujuan pembelajaran dan kompetensi dasar yang akan dicapai siswa dalam pembelajaran setiap mengawali pembelajaran dengan memanfaatkan TIK.

Aktivitas pembelajaran dilakukan secara langsung dengan menyampaikan terlebih dahulu kepada siswa kegiatan yang akan dilakukan pada hari tersebut. Hal ini dilakukan untuk membangkitkan motivasi belajar siswa agar siswa memiliki tingkat kesiapan belajar yang tinggi, sehingga apa yang diajarkan oleh guru akan mudah dimengerti dan dipahami dengan baik. Guru juga menyampaikan cakupan materi dan penjelasan uraian kegiatan sesuai silabus dan rencana pelaksanaan pembelajaran agar siswa lebih memahami dan mengerti lebih awal mengenai gambaran materi yang akan dipelajari.

Kegiatan pendahuluan ini yang dilakukan oleh guru sesuai dengan penjelasan Triwiyanto (2015), bahwa dalam kegiatan pendahuluan, pendidik sebaiknya menyiapkan peserta didik secara psikis dan fisik untuk mengikuti proses pembelajaran, memberi motivasi belajar siswa, mengajuak pertanyaanpertanyaan yang mengaitkan pengetahuan sebelumnya dengan materi yang akan dipelajari, menjelaskan tujuan pembelajaran, menyampaikan cakupan materi dan penjelasan uraian kegiatan sesuai silabus.

Kegiatan inti dalam pelaksanaan pembelajaran di Program Keahlian Seni Rupa SMK Negeri 5 Yogyakarta, guru selalu membimbing siswa untuk terlibat dalam mencari sumber informasi. Sekolah telah memberikan fasilitas komputer dan jaringan internet atau wifi dengan kecepatan 100 mbps terpasang di area lingkungan sekolah yang dapat membantu siswa dalam mencari informasi dengan menggunakan smartphone android yang dimiliki siswa. Sekolah pun memberikan keterampilan dalam penggunaan komputer dan internet dengan menyelenggarakan mata pelajaran sistem komunikasi dan digital (SIMKOMDIG) dimulai dari kelas satu. 
Hal ini dimaksudkan agar siswa mengenal dan dapat menggunakan teknologi informasi dan komunikasi, sehingga guru tidak perlu lagi mengajarkan penggunaan komputer pada siswa ketika mempelajari mata pelajaran yang lain (Muhyadi, 2013). Guru selalu melibatkan siswa mencari sumber informasi mengenai materi yang akan dipelajari dengan memanfaatkan TIK melalui internet dengan browsing, searching dan melihat tayangan dari youtube menggunakan komputer yang telah disediakan sekolah maupun dengan smartphone android yang dimiliki siswa sendiri.

Guru menggunakan pendekatan maupun metode pembelajaran yang beragam setiap pembelajaran. Metode yang digunakan dalam pembelajaran diantaranya diskusi, ceramah, praktek langsung, kerja proyek, student center learning, discovery learning, peer teaching, klasikal, tanya jawab dan konsultasi. Hal ini dilakukan guru agar dapat memberikan pengalaman belajar yang bermakna bagi siswa, sesuai dengan firman Allah dalam Q.S. An-Nahl : 125 :

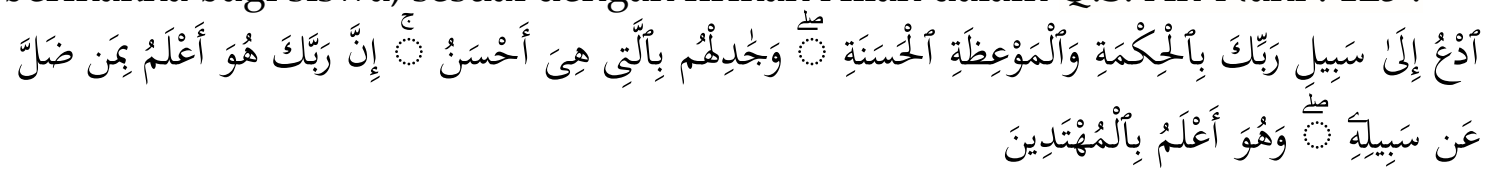

Artinya: "Serulah (manusia) kepada jalan Tuhan-mu dengan hikmah dan pelajaran yang baik dan bantahlah mereka dengan cara yang baik. Sesungguhnya Tuhanmu Dialah yang lebih mengetahui tentang siapa yang tersesat dari jalan-NYA dan Dialah yang lebih mengetahui orang-orang yang mendapat petunjuk"

Jika dikorelasikan dengan pembelajaran, ayat tersebut mengandung interpretasi tentang metode belajar dan pembelajaran berdasarkan konsep qur'ani. Guru menggunakan media pembelajaran, alat dan sumber belajar yang berbasis TIK dalam pembelajaran. Media pembelajaran yang digunakan guru dalam pembelajaran yaitu bahan tayang atau materi powerpoint (PPT), aplikasi atau corel, potoshop, blender. Alat belajar yang digunakan laptop, LCD proyektor dan komputer. Sumber belajar yang digunakan guru yaitu buku elektronik, video referensi, youtube dan internet. Guru menggunakan media pembelajaran, alat dan sumber belajar terebut berdasarkan dari kebutuhan masa kini, materi yang didapat bisa beragam dan berdasarkan kurikulum yang ada. Media pembelajaran, alat dan sumber belajar tersebut sangat mendukung dalam proses pembelajaran yang digunakan siswa dalam berinteraksi dengan media pembelajaran dan sumber belajar yang dibimbing oleh guru sehingga siswa tidak mengalami kesulitan dalam menggunakan media pembelajaran dan sumber belajar tersebut (Elistanto \& Mahmudah, 2020).

Guru memanfaatkan teknologi informasi dan komunikasi dalam pembelajaran sebagai media pembelajaran, alat dan sumber belajar. Hal ini yang menjadi ciri khas sehingga proses belajar di Program Keahlian Seni Rupa SMK Negeri 5 Yogyakarta merupakan pembelajaran berbasis teknologi informasi dan komunikasi. Perangkat fisik dari teknologi informasi dan komunikasi yang dimanfaatkan sebagai media pembelajaran, alat dan sumber belajar, yaitu dengan menggunakan LCD proyektor, komputer yang sudah dipasang di setiap kelas bahkan laptop yang dibawa oleh masing-masing guru. 
Sementara itu, sumber belajar berbentuk materi digital yang digunakan adalah media pembelajaran berbasis multimedia pembelajaran interaktif berbasis multimedia presentasi, yaitu pemanfaatan komputer untuk membuat dan menggabungkan teks, grafik, suara dan gambar bergerak. Sumber dan materi belajar ini dibuat dengan program Microsoft Powerpoint.

Pemanfaatan multimedia berbasiskan presentasi telah memberikan pengaruh yang sangat besar, diharapkan dengan menggunakan media pembelajaran utamanya presentasi dapat meningkatkan hasil belajar peserta didik. Penggunaan multimedia presentasi dalam pembelajaran bertujuan untuk mengakomodir secara keseluruhan pemanfaatan indra serta didik baik bersifat audio, visual, maupun audio visual (Chaidar, 2014). Selain aktivitas pembelajaran di kelas, siswa juga melaksanakan pembelajaran di laboratorium komputer dan di lapangan. Peran guru dalam aktivitas tersebut adalah mendampingi, mengawasi, menginformasikan, dan membimbing.

Aktivitas siswa dalam pembelajaran diantaranya mengamati, menganalisa, mengerjakan tugas, praktek, diskusi dan presentasi. Penggunaan media pembelajaran, alat dan sumber belajar berbasis teknologi informasi dan komunikasi di program keahlian seni rupa SMK Negeri 5 Yogyakarta telah digunakan oleh semua guru dan siswa yang dilaksanakan di semua kelas dan semua mata pelajaran. Guru memanfaatkan media pembelajaran, alat dan sumber belajar tersebut dengan alasan media pembelajaran, alat dan sumber belajar tersebut sesuai dengan kurikulum yang ada, sesuai dengan masa sekarang atau kekinian, menarik, sesuai dengan kebutuhan dan materi yang didapatkan bisa beragam.

Guru selalu membiasakan siswa membaca dengan memanfaatkan TIK, baik itu tugas di sekolah maupun tugas yang dikerjakan di rumah. Penugasan guru ada dua macam, yaitu tugas individu dan tugas kelompok, namun guru lebih sering memberikan tugas individu karena membuat karya itu harus dari ide kreatif siswa sendiri. Sedangkan tugas kelompok yang sering diberikan adalah diskusi dan praktek membuat karya sesuai dengan tugas yang diberikan.

Cara yang dilakukan guru dalam hal ini adalah dengan memberi motivasi, menampilkan karya-karya dari kakak kelas, menayangkan gambar dari internet dan memberikan contoh karya yang sudah jadi. Guru selalu membimbing siswa agar dapat berfikir, menganalisis, menyelesaikan masalah dan bertindak tanpa rasa takut. Guru membimbing siswa agar memiliki keterampilan dalam berfikir, menyelesaikan masalah dan bertindak tanpa rasa takut (Fauziah \& Mahmudah, 2020).

Hal ini dilakukan dengan sederhana, yaitu dengan melakukan evaluasi, apresiasi, pujian, mengangkat jempol tangan, memotivasi dan memberi masukan. Kegiatan ini sangatlah penting bagi siswa dan perlu pembiasaan di sekolah maupun di rumah, mengingat fungsi pendidikan tidak hanya untuk mentrasfer ilmu tetapi juga untuk membantu perkembangan siswa. Guru memfasilitasi siswa agar dapat belajar secara kooperatif dan kolaboratif dengan memberikan fasilitas alat, mencari informasi di internet dan memberikan tugas dengan berdiskusi (Widyaningrum, 2019). Guru juga memfasilitasi siswa agar 
dapat berkompetisi secara sehat untuk meningkatkan prestasi belajar dengan memberikan waktu 24 jam untuk berkonsultasi melalui media sosial whatsapp, memberikan semangat, memberi motivasi, mengevaluasi dan memfasilitasi alat.

Guru memfasilitasi siswa dalam membuat laporan eksplorasi dengan memberikan bimbingan, memberi fasilitas media pendukung seperti komputer untuk mengetik laporan dan membuat karya serta menyediakan printer untuk mencetak hasil laporan. Ketika menyajikan hasil kerja, guru memfasilitasi siswa dengan memberikan bimbingan, menyediakan alat dan bahan, menyiapkan media pendukung. Selain itu guru juga mendorong siswa untuk menyajikan hasil kerja dengan memanfaatkan TIK dengan memotivasi, memberikan bimbingan dan menyediakan alat untuk presentasi. TIK dalam hal ini dimanfaatkan oleh siswa sebagai sumber belajar, media dan alat pembelajaran serta untuk menyajikan hasil kerja.

Selanjutnya, guru memberikan umpan balik positif dan penguatan kepada siswa dengan memuji hasil karya siswa yang diupload di Instagram, dievaluasi, diberi contoh dan memotivasi serta memberikan hadiah. Guru juga memberikan konfirmasi terhadap hasil eksplorasi dan elaborasi siswa dengan memberikan tanggapan terhadap karya yang dihasilkan, memberi catatan, memberi saran dan membimbing siswa selama proses pembelajaran. Dan dilanjutkan dengan membuat kesimpulan di akhir pembelajaran dengan mengingatkan untuk mengumpulkan karya dan mencatat materi yang belum jelas.

Setelah itu, guru melakukan penilaian pembelajaran. Penilaian dilakukan setiap materi kompetensi dasar telah selesai dengan memberikan saran dan evaluasi terhadap karya yang dikumpulkan. Guru juga melakukan refleksi pembelajaran dengan memberikan petanyaan, menampilkan karya dan memberikan masukan terhadap hasil karya.

Guru memberikan umpan balik terhadap proses dan hasil belajar siswa dengan pujian, memberikan evaluasi dan memberikan apresiasi. Selain itu, guru juga memberikan tindak lanjut pembelajaran dengan memberikan waktu untuk remidi, perbaikan, penambahan tugas, pengulangan materi, konsultasi dan evaluasi karya. Tindak lanjut dalam pembelajaran dilakukan guru kepada siswa yang mempunyai keterampilan kurang baik itu karya yang belum selesai maupun karya yang sudah selesai dengan memberikan evaluasi dan menyuruh siswa untuk menyelesaikan dan menyempurnakan karyanya.

Di samping itu, guru juga memberikan tindak lanjut dengan remidi yang dilakukan secara berkeliling di kelas melihat kerja dan hasil kerja siswa, jika ada karya yang belum memenuhi target langsung diberi arahan dan bimbingan untuk segera merubah atau menambah karya. Guru juga memberikan layanan konseling dalam proses pembelajaran untuk tindak lanjut hasil belajar siswa. Hal ini sesuai dengan yang ditulis Haerena (Haerana, 2016) bahwa program tindak lanjut merupakan rencana yang dipersiapkan guru untuk memberikan tindak lanjut terhadap sejumlah kompetensi yang telah diberikan kepada siswa. 
Pada akhir pembelajaran guru juga menyampaikan rencana pembelajaran pada pertemuan berikutnya agar siswa dalam menghadapi pembelajaran selanjutnya bisa menyiapkan diri baik pengetahuan maupun alat yang akan digunakan. Hal ini sesuai dengan yang dikemukakan oleh Haerana (2016), bahwa menyampaikan rencana pembelajaran pada pertemuan berikutnya dapat memberikan gambaran bahwa pembelajaran yang dijalankan sestematis, terstruktur dan akan memberikan peluang kepada siswa untuk mempersiapkan diri baik pengetahuan maupun alat yang nantinya akan digunakan.

\section{KESIMPULAN}

Hasil penelitian di atas menunjukkan bahwa pelaksanaan pembelajaran berbasis teknologi informasi dan komunikasi di program keahlian seni rupa SMK Negeri 5 Yogyakarta dilaksanakan dalam proses tatap muka di kelas. Pemanfaatan teknologi informasi dan komunikasi sebagai media pembelajaran, alat dan sumber belajar. Pembelajaran dilakukan oleh guru dengan menampilkan konten digital atau media presentasi yang dibuat guru sendiri, dari sekolah maupun men-download dari internet sebagai materi bahan tayang dalam pembelajaran dengan menggunakan alat komputer dan LCD proyektor yang disediakan oleh sekolah maupun menggunakan laptop milik guru pribadi. Siswa dalam pelaksanaan pembelajaran memanfaatkan teknologi informasi dan komunikasi menggunakan alat komputer yang disediakan oleh sekolah untuk membuat tugas karya individu maupun kelompok. Sumber belajar yang digunakan dalam pembelajaran berbasis teknologi informasi dan komunikasi yaitu dengan mencari sumber belajar di internet menggunakan komputer yang disediakan sekolah maupun menggunakan smartphone android yang dimiliki siswa.

\section{DAFTAR PUSTAKA}

Aka, K. A. (2017). Pemanfaatan Teknologi Informasi dan Komunikasi (TIK) Sebagai Wujud Inovasi Sumber Belajar di Sekolah Dasar. Elementary School Education Journal, 1(2), 28-37.

Amin, M. M. (2017). Strategi implementasi Revitalisasi SMK: 10 langkah Revitalisasi SMK. Jakarta: Kementrian Pendidikan dan Kebudayaan.

Chaidar, H. (2014). Pemanfaatan Teknologi Informasi dan Komunikasi dalam Pembelajaran di SMA Muhammadiyah Tarakan. Jurnal Kebijakan Dan Pengembangan Pendidikan, 2(2), 184-192.

Chandra, V., \& Lloyd, M. (2008). The Methodological Nettle: ICT and Student Achievement. British Journal of Educational Technology, 39(6), 1087-1098.

Elistanto, R., \& Mahmudah, F. (2020). Evaluasi Efektivitas Manajemen Pembelajaran Guru Produktif Otomotif SMK. Jurnal Studi Manajemen Pendidikan, 4(1), 102-115. 
Fauziah, S. B., \& Mahmudah, F. N. (2020). Strategies of Science Teachers in Overcoming the Factors. International Journal of Educational Management and Innovation, 1(1), 39-49.

Haerana. (2016). Manajemen Pembelajaran Berbasis Standar Proses Pendidikan; Teori dan Aplikasinya (Pertama). Yogyakarta: Media Akademi.

Husnurofik, Z., Mahmudah, F., \& Husaini, U. (2019). A Systematic Review on Sustainable Human Resource Management: A Framework for Managing Training in The Indonesian Police Force. First International Conference on Progressive Civil Society, 317(IConProCS), 160-164.

Isjoni, I. A., \& Rosnaini, M. (2009). ICT untuk Sekolah Unggul. Yogyakarta: Pustaka Pelajar.

Khusni, W., \& Mahmudah, F. N. (2020). he Principal 's Managerial Ability in Developing Effective. International Journal of Educational Management and Innovation, 1(2), 99-108.

Leese, M. (2009). Out of Class-Out of Mind? The Use of a Virtual Learning Environment to Encourage Student Engagement in Out of Class Activities. British Journal of Educational Technology, 40(1), 70-77.

Mahmudah, F. N. (2016). Keefektifan Human Capital Investment Pendidikan Tenaga Kependidikan di Universitas Negeri Yogyakarta. Jurnal Akuntabilitas Manajemen Pendidikan, 4(1), 77-87.

Muhyadi. (2013). Qualification and Competencies of School. Jurnal Kependidikan, 1(43), 39-50.

Relmasira, S. C., \& Thrupp, R. M. (2016). Reservice Teachers on Teaching with and About ICT: An Indonesian Study. Scholaria, 6(3), 163-172.

Retalis, S., Georgiakakis, P., \& Dimitriadis, Y. (2006). Eliciting Design Patterns for E-Learning Systems. Computer Science Education, 16(2), 105-118.

Rusman, D. K., \& Riyana, C. (2013). Pembelajaran Berbasis Teknologi Informasi dan Komunikasi: Mengembangkan Profesionalitas Guru. Jakarta: Rajawali Pers.

Syakdiyah, A. (2019). Active Learner Strategies in Era of Disruption: a Literature Review. Proceedings of the First International Conference on Progressive Civil Society, 317(1), 165-168.

Triwiyanto, T. (2015). Manajemen Kurikulum dan Pembelajaran. Jakarta: Bumi Aksara.

Wena, M. (2009). Strategi Pembelajaran Inovatif Kontemporer. Jakarta: Bumi Aksara.

Widyaningrum, K. N., \& Mahmudah, F. N. (2019). Kreasi Iklim Sekolah melalui Gerakan Sekolah Menyenangkan di SD Muhamammadiyah Mantaran. Profesi Pendidikan Dasar, 6(2), 115-128. https://doi.org/10.23917/ppd.v1i2.9259. 